Araştırma Makalesi - Research Article

\title{
Silika Aerojel katkılı Alkali-Aktive Edilmiş Uçucu Kül Harçlarının Mekanik, Por Yapısı ve Mikro Yapı Özellikleri
}

ÖZ

Silika aerojeller, çimento matrisine dâhil edildiklerinde yüksek poroziteleri aracıllğıyla çimento esaslı malzemelerin akustik ve termal yalıtım performanslarına katkı sunabilmektedirler. Silika aerojel partikülleri, yüksek porozitelerine rağmen mekanik zorlamalar altında ihmal edilemeyecek düzeyde mekanik özellikler de gösterebilmektedirler. Bu çalışmada çimento ağıllığınca düşük katkı oranlarında $(\% 0.25$ ve $\% 0.50)$ çimento matrisine dâhil edilen silika aerojellerin alkali - aktive edilmiş uçucu kül harçlarının mekanik, por yapısı ve mikro yapı özelliklerine olan etkisi araştırılmıştır. Deneysel çalışmadan elde edilen sonuçlar, ortalama $20 \mathrm{MPa}$ basınç dayanımına sahip uçucu kül harçlarının basınç etkisi altındaki tokluk ve pik - sonrası tokluk kapasitelerinin sırasıyla yaklaşı $\% 27$ ve $\% 70$ düzeylerinde artabileceğini ortaya koymaktadır. Harç numunelerinin por yapısında mikro ve kapiler boyuttaki por çaplarının değişimine bağlı olarak elde edilen tokluk kazancı, gelecekte eşdeğer basınç dayanımları altında deformasyon davranışı geliştirilmiş silika aerojel katkılı blok elemanların üretimi için yenilikçi bir tasarım fikrini ortaya koymaktadır.

Anahtar Kelimeler-Silika Aerojel, Uçucu Kül, Alkali-Aktive Edilmiş Harç, Tokluk, Porozite

1*Sorumlu yazar iletişim: leventbostanci@beykent.edu.tr (https://orcid.org/0000-0002-4686-9102) Inşaat Teknolojisi Programı, Beykent Üniversitesi, İstanbul 


\title{
Mechanical, Pore Structure and Microstructural Properties of Alkali-Activated Fly Ash Mortars Containing Silica Aerogel
}

\begin{abstract}
Inclusion of silica aerogels in cement matrix can lead to an enhancement in thermal and acoustic properties of cement - based materials due to the high porosity values of silica aerogel particles. Despite their high porosity values, silica aerogel particles can also show sufficient mechanical performance under stress. In this study, mechanical, pore structure and microstructure properties of alkali - activated fly ash mortars containing a small amount of silica aerogel powder ( $0.25 \%$ and $0.50 \%$ of binder, by weight) were investigated. The results obtained from the experimental study reveal that the compressive toughness and compressive post-peak toughness capacities of fly ash mortars with an average compressive strength of $20 \mathrm{MPa}$ could increase by about $27 \%$ and $70 \%$, respectively. Toughness development obtained via the change in the micro and capillary pore formation in the pore structure of the mortar samples presents an innovative design idea for the production of silica aerogelincorporated mortar blocks with improved deformation behavior under equivalent compressive stress.
\end{abstract}

Keywords-Silica Aerogel, Fly Ash, Alkali-Activated Mortar, Toughness, Porosity 


\section{I.GİRIŞ}

\section{A. Arka Plan}

Enerjinin ekonomik olarak kullanılması fikri, tüm endüstriyel alanlarda olduğu gibi inşaat sektöründe de uygulanması kaçınılmaz bir zorunluluk haline gelmiştir. İnşaat sektöründe yürütülen faaliyetler yüksek düzeyde enerji tüketimini gerektirmektedir. Artan enerji tüketimi ile global ısınma düzeyi de artmakta ve bu durum gerek ekosistem gerekse ekonomi açısından telafisi mümkün olmayan sonuçlar doğurmaktadır [1]. Çimento teknolojisinde $1 \mathrm{~kg}$ çimento üretimi esnasında yaklaşı $1.0 \mathrm{~kg} \mathrm{CO}_{2}$ salınımı gerçekleşmekte ve eş zamanlı olarak da kg başına $1.5 \mathrm{kWh}$ enerji harcanmaktadır [2]. Çimento üretiminin yüksek maliyeti ve $\mathrm{CO}_{2}$ salınımı göz önüne alınarak günümüzde çimento harçları yerine bağlayıcı malzeme içeriğinde çimento miktarının azaltıldığı çevredostu harç tasarımları üzerine sıkça deneysel çalışmalar gerçekleştirilmektedir $[3,4]$.

Günümüzde çimento harçlarına alternatif olarak üretilen alkali - aktive edilmiş harçlar aracılığıyla çimento üretimi kaynaklı $\mathrm{CO}_{2}$ salınımı \%80 düzeyinde azaltılabilmektedir. Bu noktada; alkali - aktive edilmiş harçların yaygınlaşması ekosistemin geleceği açısından önem arz etmektedir [5]. Alkali-aktive edilmiş harçlarda toz formdaki alüminosilikat kaynağı değişen kür ve nem koşullarında alkali aktivatör ile kimyasal reaksiyona girerek yüksek dayanımlı, üstün durabilite özelliklerine sahip ve düşük hidratasyon 1sılı harç oluşturabilmektedir. Alkali-aktive edilmiş harçlarda alüminosilikat kaynağı olarak ise endüstriyel yan ürün olarak tabir edilen yüksek firın cürufu ve uçucu kül sıkça tercih edilmektedir [6].

Uçucu küller, kimyasal kompozisyonlarında yer alan kalsiyum oksit $(\mathrm{CaO})$ miktarına bağlı olarak ASTM C-618 [7]'e göre C ve F sınıfı uçucu küller olmak üzere iki farklı tipte tanımlanmaktadır. C sınıfı uçucu küller, santrallerde linyit kömürünün yakımı ile elde edilmektedir. Kimyasal kompozisyonunda \%20'den daha fazla $\mathrm{CaO}$ barındıran $\mathrm{C}$ sınıfı uçucu küllerde $\mathrm{SiO}_{2}, \mathrm{Al}_{2} \mathrm{O}_{3}$ ve $\mathrm{Fe}_{2} \mathrm{O}_{3}$ ' ün toplam miktarı \%50-70 aralığında değişmektedir. $\mathrm{F}$ sınıfı uçucu küller ise antrasit veya bitümlü kömür yakımı neticesinde elde edildikleri için kimyasal kompozisyonlarında genellikle \%10'dan daha düşük seviyede $\mathrm{CaO}$ barındırırlar. F sınıfı uçucu küllerde $\mathrm{SiO}_{2}$, $\mathrm{Al}_{2} \mathrm{O}_{3}$ ve $\mathrm{Fe}_{2} \mathrm{O}_{3}$ 'ün toplam miktarı da \% 70'ten fazladır [8 -10]. Uçucu küller, kimyasal kompozisyonlarında yüksek düzeyde $\mathrm{Al}_{2} \mathrm{O}_{3}$ ve $\mathrm{SiO}_{2}$ içerdiklerinden alkali aktivasyonu için bağlayıcılık potansiyeli açısından oldukça cazip gözükmektedirler [11].

\section{B. Literatür Taramasl}

Önceki deneysel çalışmalarda, harç karışımlarındaki çimentonun uçucu kül ile yer değişiminin harcın mekanik özelliklerine olan etkisi sıkça incelenmiştir. Literatürde uçucu kül içeren karışım numunelerinde kontrol durumuna kıyasla daha yüksek basınç dayanımlarının elde edilebilmesi için uçucu kül içeriğinin \%10 veya \%20 gibi düşük düzeylerde kullanılması önerilmiştir [12]. Karahan ve Atis [13] beton karışımlarında ağrılıkça \%15 ve \%30 düzeylerinde çimento ile uçucu külü yer değiştirerek fiber katkılı beton numunelerinin mekanik ve durabilite özelliklerinin değişimini araştırdılar. Sonuçlar, artan uçucu kül içeriği ile dayanımların düştüğünü ve kontrol numunesine kıyasla \%15 ve \%30 düzeylerindeki uçucu kül içeriği için dayanımlarda sırasıyla \%17 ve \%30 düzeylerde kayıpların oluştuğunu göstermiştir. Yerramala vd. [14] ürettikleri harç karışımlarında \% 0-25 oranlarında çimento ile uçucu külü yer değiştirerek \%25 oranındaki uçucu kül içeriği için basınç dayanımlarını 7. ve 28. günlerde sırasıyla 10.4 ve 19.6 MPa olarak tespit ettiler. Yüksek basınç dayanımı hedefi için optimum uçucu kül içeriğinin \%10 olmasını gerektiğini rapor ettiler. Al Zaidi vd. [15] harç karışımlarında bağlayıcı malzeme içeriğinde \%50 düzeyinde uçucu kül içeren harç numuneleri ürettiler. Kullanılan uçucu kül içeriğinin yüksek düzeyine bağlı olarak çimento matrisinde uzun yıllar süreceğini öngördükleri yavaş hidrolik etkileşime dikkat çektiler.

Endüstriyel atık türü bağlayıcıların çimento yerine kısmi düzeyde kullanıldığı harçlarda numunelerin basınç dayanımlarındaki kayıplara ilaveten tokluk kapasitelerinin de azaldığı bilinmektedir [16]. Azalan tokluk davranışının telafi edilmemesi durumu, atık türü bağlayıcı içeren harçların kullanımını kısıtlayarak eko sistem açısından sunduğu avantajlardan yararlanılmasının önünde engel teşkil etmektedir. Küresel formdaki uçucu kül tanecikleri, çimento matrisinde kısmen kimyasal bağ etkileşimini zayıflatabilmektedir [17]. Guades [18] uçucu kül içerikli jeopolimer harçlarının mekanik özelliklerinin kum - uçucu kül oranına bağlı olarak değişimini araştırmıştır. Uçucu kül harçları için $12.4 \mathrm{MPa}$ lık basınç dayanımı değeri altında oldukça gevrek bir kırılma 
mekanizması tespit edilmiştir. Bu sebeple uçucu kül harçlarında tokluk özelliklerinin gelişimi için genellikle lif katkısı tercih edilmektedir. Xu vd. [19] uçucu kül esaslı jeopolimer harçlarında 8 ve $12 \mathrm{~mm}$ uzunluğundaki PVA lifleri kullanarak eğilme etkisi altındaki tokluk davranışını incelediler. Sonuçlar, tokluk özelliklerinin $12 \mathrm{~mm}$ uzunluğundaki PVA lifleri aracılığı ile \%1300 düzeyinde gelişebileceğini göstermiştir.

Malzeme biliminde çimento esaslı malzemelerin mekanik ve yalıtım performanslarının geliştirilmesi adına nano boyuttaki malzemelerin çimento matrisine dahil edilmesi üzerine de sıkça çalışılmaktadır. Nanomalzemeler, kalsiyum silikat yapısı içerisinde genellikle boşluk doldurarak mikro yapı özelliklerini geliştirmekte ve kökenlerine bağlı olarak aynı zamanda hidrolik aktiviteleri vasıtasıyla da hidratasyon sürecine ciddi düzeyde etki edebilmektedir [20]. Son yıllarda, nano-malzemeler arasında silika aerojelleri esas alan çalışmalar hızla artmaktadır. Silika aerojeller, hidrolik aktive göstermemekle birlikte kendilerine özgü por yapısı ile yüksek düzeydeki hava içeriğine rağmen katı iskeletlerini koruyacak şekilde üretilmektedir [21]. Dünyanın en hafif katısı olarak kabul edilen silika aerojellerin çimento esaslı karışımlarda kullanılması genellikle malzemelerin termal yalıtım [22-26] veya akustik yalıtım [27] performanslarının arttırılması üzerine odaklıdır. Ancak, silika aerojeller \%99.8 düzeyine erişebilen por hacmine rağmen kendi kütlelerinin 1600 katı kadar da yük taşıyabilmektedirler [28]. Partikül yoğunluklarının, hava partiküllerine kıyasla $4-5$ kat daha fazla olduğu bilinmektedir [29]. Alkali- aktive edilmiş harçlarda silika aerojellerin düşük katkı oranlarında kullanımına yönelik çalışmalar sınırlı düzeydedir. Yapılan çalışmalar, eşit aktivatör dozajı için karışımlarda optimum düzeyde artan aerojel katkısı ile kısmi olarak dayanım artışının saptanabileceğini göstermektedir [4].

Çimento esaslı malzemelerde silika aerojeller genellikle yüksek yalıtım hedefleri doğrultusunda kum ile yer değiştirilerek yüksek düzeylerde kullanılmakta ve kaçınılmaz olarak eğilme ve basınç dayanımlarında büyük düşüşler saptanmaktadır [15]. Yüksek dayanımlı beton üretiminde \%50 düzeyinde kullanılan silika aerojel içeriği sebebiyle basınç dayanımı $20 \mathrm{MPa}$ seviyesine indirgenmektedir [30]. Meydana gelen dayanım düşüşleri esasen silika aerojellerin çimento esaslı malzemelerde hafif agrega olarak fonksiyonel rol üstlenmesi ile alakalıdır. Hanif vd. [23] 28 günlük yaşta yüksek düzeydeki silika aerojel içeriği için $1187 \mathrm{~kg} / \mathrm{m}^{3}$ 'lük birim hacim ağırlığa karşın basınç dayanımını 18.63 MPa olarak tespit etmişlerdir. Aynı kür süresi sonunda ise eğilme dayanımı 3.66 MPa olarak saptanmıştır. Liu vd. [24] ise hacimce \%60 oranında aerojel içeren numunelerde 2.15 MPa'lık basınç dayanımı ve $0.45 \mathrm{MPa}$ 'lık eğilme dayanımı tespit etmişlerdir. Öte yandan, karışımlarında silika aerojelin çimento katkı maddesi olarak kullanımında ise, silika aerojel katkısının düşük içeriği nedeniyle mekanik dayanımlarda genellikle ciddi düzeyde düşüşler görülmemektedir [4]. Bostancı vd. [26] silika aerojel içeriğinin \% 0.1 den \% 0.7 e kadar olan artışı için basınç dayanımlarında benzer dayanım değerlerini saptarken \%1.0 aerojel katkı oranında ise kontrol numunesine kıyasla 56.5 $\mathrm{MPa}$ ' dan 57.0 MPa' kadar kısmi bir artışında saptanabileceğini ortaya koymuştur.

\section{Araştırmanın Önemi}

Silika aerojeller üzerine yakın geçmişte yapılan çalışmalar, silika aerojellerin yüksek porozite değerlerini göz önüne alarak genellikle numunelerin akustik, yangın ve ısıl yalıtım performanslarına olan katkıları üzerine odaklanmıştır. Bu çalışmada ise silika aerojellerin yüksek porozite değerlerine rağmen sahip oldukları mekanik özellikler göz önüne alınarak alkali - aktive edilmiş uçucu kül harçlarının basınç etkisi altındaki tokluk özelliklerine olan etkisi araştırılmıştır. Çalışmanın odak noktası, ortalama $20 \mathrm{MPa}$ basınç dayanımına sahip harç numunelerindeki deformasyon davranışının silika aerojel katkısı ile değişiminin araştırılması üzerinedir. Silika aerojel katkısının eşdeğer basınç dayanımları altında numunelerin deformasyon gelişimine olan etki mekanizmasının anlaşılması özellikle yapı duvarlarında kullanılacak çimento esaslı ve silika aerojel katkılı blok elemanların gelecekteki tasarım girişimleri için önem arz etmektedir.

\section{II.MALZEME VE YÖNTEM}

\section{A. Kullanılan Malzemeler}

1) Alkali Aktivatör: Harç karışımlarında alkali-aktivasyon işlemi sodyum karbonat $\left(\mathrm{Na}_{2} \mathrm{CO}_{3}\right)$ ile gerçekleştirilmiştir. Kullanılan $\mathrm{Na}_{2} \mathrm{CO}_{3}$ için kimyasal kompozisyon Tablo 1' de sunulmuştur. 


\begin{tabular}{|c|c|c|}
\hline & $\begin{array}{l}\text { BŞEÜ Fen Bilimleri Dergisi } \\
7(2), 588-608,2020\end{array}$ & $\begin{array}{l}\text { BSEU Journal of Science } \\
\text { DOI: } 10.35193 / \text { bseufbd.719911 }\end{array}$ \\
\hline & & 88-7575 (http://dergipark.gov.tr/bseufbd) \\
\hline
\end{tabular}

Tablo 1. Kullanılan $\mathrm{Na}_{2} \mathrm{CO}_{3}{ }^{\prime}$ ün kimyasal kompozisyonu.

\begin{tabular}{|c|c|}
\hline Bileşen & $(\%)$ \\
\hline $\mathrm{Na}_{2} \mathrm{CO}_{3}$ & Min. 99.5 \\
\hline $\mathrm{NaCl}$ & Max. 0.1 \\
\hline $\mathrm{Na}_{2} \mathrm{SO}_{4}$ & Max. 0.1 \\
\hline Çözünmeyen kalıntı & Max. 0.05 \\
\hline
\end{tabular}

2) Băglayıcı Malzemeler: Üretilen harç karışımlarından bağlayıcı malzeme olarak CEM I 42.5 R tipi çimento ile uçucu kül kullanılmıştır. Kullanılan uçucu kül, $\mathrm{SiO}_{2}+\mathrm{Al}_{2} \mathrm{O}_{3}+\mathrm{Fe}_{2} \mathrm{O}_{3}$ miktarının (\%68.31) \%50'nin üzerinde olması dikkate alındığında ASTM C-618 [7] standardına göre C sınıfı uçucu kül olarak tanımlanmaktadır. Kullanılan çimento ve uçucu küle ait kimyasal kompozisyon ve fiziksel özellikler Tablo 2' de gösterilmiştir.

Tablo 2. Çimento ve uçucu kül için kimyasal kompozisyon ve fiziksel özellikler.

\begin{tabular}{|c|c|c|}
\hline & Çimento & Uçucu kül \\
\hline \multicolumn{3}{|c|}{ Kimyasal kompozisyon (wt/wt \%) } \\
\hline $\mathrm{SiO}_{2}$ & 19.78 & 43.56 \\
\hline $\mathrm{Al}_{2} \mathrm{O}_{3}$ & 5.13 & 20.57 \\
\hline $\mathrm{Fe}_{2} \mathrm{O}_{3}$ & 3.67 & 4.18 \\
\hline $\mathrm{CaO}$ & 63.27 & 24.54 \\
\hline MgO & 2.12 & 1.76 \\
\hline $\mathrm{SO}_{3}$ & 2.94 & 1.44 \\
\hline $\mathbf{K}_{2} \mathbf{O}$ & 0.87 & 1.29 \\
\hline $\mathrm{Na}_{2} \mathrm{O}$ & 0.22 & 0.32 \\
\hline $\mathrm{Cl}^{-}$ & 0.01 & 0.007 \\
\hline \multicolumn{3}{|c|}{ Fiziksel özellikler } \\
\hline Yoğunluk (g/cm³) & 3.16 & 2.4 \\
\hline Özgül yüzey alanı $\left(\mathrm{cm}^{2} / \mathrm{g}\right)$ & 3580 & 2900 \\
\hline
\end{tabular}

3) Kum: Harç karışımlarında ince agrega olarak TS EN 196-1 [31] standardına uygun olarak hazırlanmış Rilem kumu kullanılmıştır.

4) Silika Aerojel: Harç karışımlarında Ensate Yalıtım Mühendislik Proje San. Ve Tic. Ltd. Şti tarafından sipariş üzerine üretilmiş olan toz formdaki silika aerojel kullanılmıştır. Kullanılan silika aerojele ait fiziksel özellikler Tablo 3' de görülmektedir. 


\begin{tabular}{|c|c|c|}
\hline & $\begin{array}{l}\text { BŞEÜ Fen Bilimleri Dergisi } \\
7(2), 588-608,2020\end{array}$ & $\begin{array}{l}\text { BSEU Journal of Science } \\
\text { DOI: } 10.35193 / \text { bseufbd.719911 }\end{array}$ \\
\hline & & 88-7575 (http://dergipark.gov.tr/bseufbd) \\
\hline
\end{tabular}

Tablo 3. Kullanılan silika aerojelin fiziksel özellikleri.

\begin{tabular}{|c|c|}
\hline Yüzey alanı (m²/gr) & $790-840$ \\
\hline Ortalama por çapı (nm) & $8-10$ \\
\hline Porozite $(\%)$ & $>\% 94$ \\
\hline Görünür yoğunluk $\left(\mathbf{k g} / \mathbf{m}^{3}\right)$ & $90-100$ \\
\hline Yüzey grubu & $-\mathrm{OH}$ \\
\hline
\end{tabular}

\section{B. Karışım Oranları}

Deneysel çalışmalar kapsamında üretilen harç numunelerinde harç karışımlarına düşük katkı oranlarında ilave edilen silika aerojel katkısının numunelerin mekanik, por yapısı ve mikro yapı özelliklerine olan etkisini araştırmak için 5 farklı katkı oranlarında harç karışımları oluşturulmuştur. Harç karışımlarında bağlayıcı malzeme olarak çimento ve uçucu külden oluşan hibrit bağlayıcı kullanılmıştır. Ortalama $20 \mathrm{MPa}$ düzeyinde basınç dayanımı hedeflenen deneysel çalışmalarda uçucu külün çimentoya kıyasla daha düşük hidrolik aktivitesi sebebiyle tüm karışımlarda uçucu kül- çimento yer değişimi \%50 düzeyinde gerçekleştirilmiştir. Silika aerojel katkısı, karışımlara bağlayıcı malzeme ağırlığınca \%0.25 (1.125 g) ve \%0.50 (2.25 g) katkı oranlarında ilave edilmiştir. Literatürdeki deneysel çalışmalarda karbonat kökenli alkali aktivatörlerin bağlayıcı malzeme içeriğinde yüksek düzeyde atık türü bağlayıcı bulunduran harçlarının mekanik performanslarına katkı sunabildiği bilinmektedir [4]. Bu sebeple, karışımlardaki uçucu külün çimentoya nazaran düşük hidrolik aktivesini geliştirmek için bağlayıcı malzeme ağırlığınca \%0.1 (0.45 g) ve \%0.2 (0.9 g) dozajlarında sodyum karbonat da alkali aktivatör olarak karışımlarda kullanılmıştır. Karışımlarda su/bağlayıcı oranı 0.50 olarak düzenlenmiş ve karma suyu olarak şebeke suyu kullanılmıştır. Karışımlarda silika aerojel içermeyen K1 numunesi "kontrol numunesi” olarak adlandırılırken rölatif olarak \%0.25 aerojel katkılı numuneler "düşük aerojel içerikli numuneler”, \%0.50 aerojel katkılı numuneler ise "yüksek aerojel katkılı numuneler" olarak nitelendirilmiştir. Harç karışım oranları Tablo 4" de görülmektedir.

Tablo 4. Harç karışım oranları.

\begin{tabular}{|c|c|c|c|c|c|c|c|}
\hline Karışım numunesi & $\begin{array}{c}\text { Aerojel } \\
(\mathbf{g})\end{array}$ & $\begin{array}{c}\mathbf{N a}_{2} \mathbf{C O}_{3} \\
(\mathbf{g})\end{array}$ & Uçucu kül (g) & Çimento (g) & Su/Bağlayıcı & $\begin{array}{c}\text { Su } \\
\text { (mu) }\end{array}$ & Kum \\
(g)
\end{tabular}




\section{Numune Hazırlanmasl, Kür Koşulları ve Uygulanan Deneyler}

Deneysel çalışmalar kapsamında TS EN 196-1 [31] standardına uygun olarak her bir karışımdan üçer adet olmak üzere 40x40x160 mm ölçülerinde tek tip prizmatik harç numuneleri üretilmiştir. Deneylerde kullanılan silika aerojel partiküllerinin karışımlardaki homojenliğini arttırmak amacıyla başlangıçta kuru bir karıştırma işlemi uygulanmıştır. Karışımlara su ilavesi azar azar yapılmış ve aerojel partiküllerinin bağlayıcı malzeme ile tamamen kaplanmasına özellikle dikkat edilmiştir. Üretilen taze harç karışımları kalıp içerisine alındıktan sonra etkin bir vibrasyon işlemine tabi tutulmuştur. Harç numuneleri laboratuvar koşullarında 24 saat kalıpta bekletildikten sonra kalıptan çıkarılmış ve 2,7 ve 28 günlük farklı kür periyotları için $20 \pm 2{ }^{\circ} \mathrm{C}$ sıcaklığındaki kür havuzuna alınmıştır. Kür süresini tamamlayan harç numuneleri sırasıyla basınç, porozimetre ve mikro yapı analizi testlerine tabi tutulmuşlardır.

Silika aerojel katkılı harç numunelerinin basınç etkisi altındaki mekanik özelliklerini tespit etmek amacıyla 2, 7 ve 28 günlük kür sürelerinin ardından harç numunelerine öncelikli olarak deformasyon kontrollü basınç testi uygulanmıştır. Test esnasında deformasyon artış hızı $0.1 \mathrm{~mm} / \mathrm{dk}$. olarak ayarlanmış ve numunelerin basınç etkisi altındaki eksenel deformasyonları doğrusal değişken diferansiyel transformatörler (LVDT'ler) aracıllğı ile ölçülerek kaydedilmiştir. Bu amaçla test esnasında öncelikle numunelerde oluşan basınç yükü deformasyon verileri kaydedilmiş ve elde edilen veri okumaları, yük - deformasyon eğrisini çizmek için bilgisayara aktarılmıştır. Karışım numunesinin basınç dayanımı, üç adet test sonucunun ortalaması alınarak TS EN 1015-11[32] standardı esaslarına göre tespit edilmiştir. Deformasyon kontrollü olarak gerçekleştirilen test sayesinde numunelerin basınç etkisi altındaki dayanımlarının yanı sıra elde edilen gerilme - birim şekil değiştirme diyagramları aracılığı ile basınç modülü, basınç tokluğu, pik - öncesi basınç tokluğu ve pik - sonrası basınç tokluğu özellikleri de 2, 7 ve 28 günlük kür süreleri için ayrıca saptanabilmiştir.

Basınç dayanımı testinden geriye kalan parçalar üzerinden cıva porozimetresi testi gerçekleştirilmiştir. Porozimetre testi 28 günlük numune parçalarına uygulanmış ve Micromeritics marka porozimetre cihazı ile gerçekleştirilmiştir. Cihaz 3,0 - 360,000 nanometre (nm) çap aralı̆̆ındaki por çaplarını tespit edilebilmektedir. Cıva porozimetresi analizi aracılı̆̆ numunelerde porozite, ortalama por çapı, kümülatif por hacmi - por çapı ilişkileri ve spesifik çap aralıklarındaki por içeriği dağılımları saptanmıştır.

Cıva porozimetresi analizine benzer şekilde 28 günlük basınç testinden geriye kalan numune parçaları üzerinden harç numunelerinin mikro yapı özelliklerinin tespiti amacıyla SEM analizi gerçekleştirilmiştir. Basınç testi sonrasında oluşan kırılma yüzeyi üzerinden hassas olarak alınan toz halindeki numune parçaları mikro yapı analizi için kullanılmıştır. SEM analizleri LEO 1430 VP model SEM cihazı ile gerçekleştirilmiştir.

\section{III.BULGULAR VE TARTIŞMALAR}

\section{A. Basınç Dayanımı Test Sonuçları}

1) 2 Günlük Numunelerde Basınç Dayanımı: Harç numunelerinde 2 günlük kür süresinin tamamlanmasının ardından basınç dayanımları $9.14-10.89 \mathrm{MPa}$ aralığında tespit edilmiştir. Numuneler için elde edilen basınç gerilmesi - birim kısalma ilişkisi Şekil 1' de görülmektedir. 


\begin{tabular}{|c|c|c|}
\hline & $\begin{array}{l}\text { BŞEÜ Fen Bilimleri Dergisi } \\
7(2), 588-608,2020\end{array}$ & $\begin{array}{l}\text { BSEU Journal of Science } \\
\text { DOI: } 10.35193 / \text { bseufbd.719911 }\end{array}$ \\
\hline & & 58-7575 (http://dergipark.gov.tr/bseufbd) \\
\hline
\end{tabular}

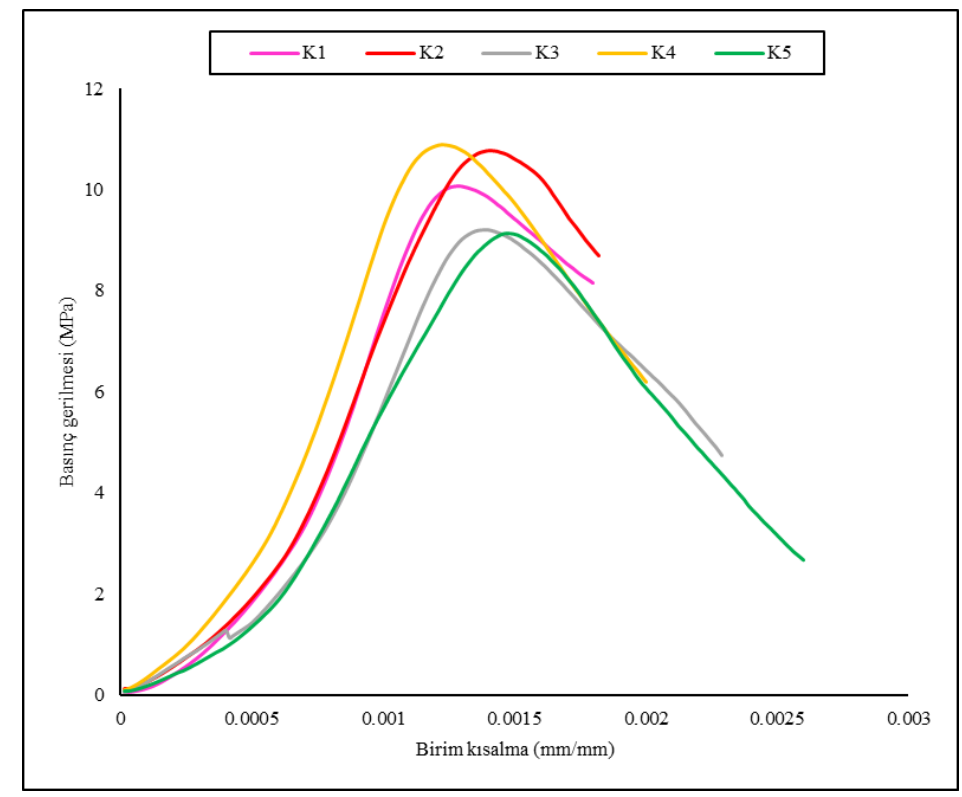

Şekil 1. 2 günlük numunelerde gerilme - birim kısalma ilişkisi.

Aerojel katkısı içermeyen kontrol numunesinde 2 günlük kür süresi sonunda $10.08 \mathrm{MPa}$ 'l1k basıç dayanımı tespit edilmiştir. Eşit aktivatör dozajında, karışımlara ilave edilen $\% 0.25$ ve \%0.50 katkı oranlarındaki silika aerojel katkıs1 nedeniyle K2 ve K4 numunelerinde kontrol numunesine sirasıly \%6.74 ve \%8.03 düzeylerinde dayanım artışları tespit edilmiştir. Öte yandan; eşit aerojel katkı oranlarında artan aktivatör dozajı basınç dayanımlarında kısmi oranda düşüşlere sebep olmaktadır. Karışımlarda \%0.1'den \%0.2'e çıkan aktivatör dozaj1 nedeniyle K2 numunesine k1yasla K3 numunesinde \%14.4 ve K4 numunesine kiyasla K5 numunesinde \%16.06 düzeylerinde düşüşler saptanmıştır.

Harç karışımlarına eşit aktivatör dozajında ilave edilen düşük düzeydeki aerojel katkısı, hidratasyonun ilk 2 günlük periyodu sonunda numunelerin dayanım özelliklerinin yanı sıra basınç etkisi altındaki deformasyon kapasitelerine de olumlu yönde etki etmiştir. K1 numunesine kıyasla K4 numunesinde kırılma anında \%11.76 seviyesinde daha yüksek deformasyon yeteneği gözlemlenmiştir. K2 numunesinde de K1 numunesi ile eşit düzeyde deformasyon kapasitesi saptanmıştır. Bu noktada; \%0.25 katkı oranındaki aerojel içeriğinin dayanım artışına olanak sağlarken deformasyon davranışını değiştirmediği ancak artan aerojel içeriğinin kırılma anındaki deformasyon kapasitesine dayanıma sunduğu katkıdan daha da fazlasını sunabildiği söylenebilir. Bununla birlikte; eşit aerojel katkı oranında artan aktivatör dozajının 2 günlük kür süresi sonunda numunelerin deformasyon davranışını son derece olumlu etkilediği görülmektedir. Artan aktivatör dozajı sebebiyle kırılma anında, K2 numunesine k1yasla K3 numunesinde \%29.41 ve K4 numunesine k1yasla K5 numunesinde \%36.84 düzeylerinde daha yüksek deformasyon kapasiteleri tespit edilmiştir. Özellikle K5 numunesi için tespit edilen deformasyon kapasitesindeki artış kontrol numunesi ile karşılaştırıldığında saptanan \%52.94 düzeyindeki deformasyon kapasite gelişimi oldukça değerlidir. 2 günlük kür süresi için tespit edilen sonuçlar, eşit aerojel katkı oranlarında artan aktivatör dozajının numunelerin dayanım değerlerine kıyasla deformasyon kapasitelerine katkı sağladığını işaret etmektedir.

2) 7 günlük numunelerde basınç dayanımı: Şekil 2 'de 7 günlük numunelere ait basınç gerilmesi - birim deformasyon ilişkisi görülmektedir. Numunelerin basınç dayanımları 13.11-15.2 MPa aralığında saptanmıştır. 


\begin{tabular}{|c|c|c|}
\hline & $\begin{array}{l}\text { BŞEÜ Fen Bilimleri Dergisi } \\
7(2), 588-608,2020\end{array}$ & $\begin{array}{l}\text { BSEU Journal of Science } \\
\text { DOI: } 10.35193 / \text { bseufbd.719911 }\end{array}$ \\
\hline & & 88-7575 (http://dergipark.gov.tr/bseufbd) \\
\hline
\end{tabular}

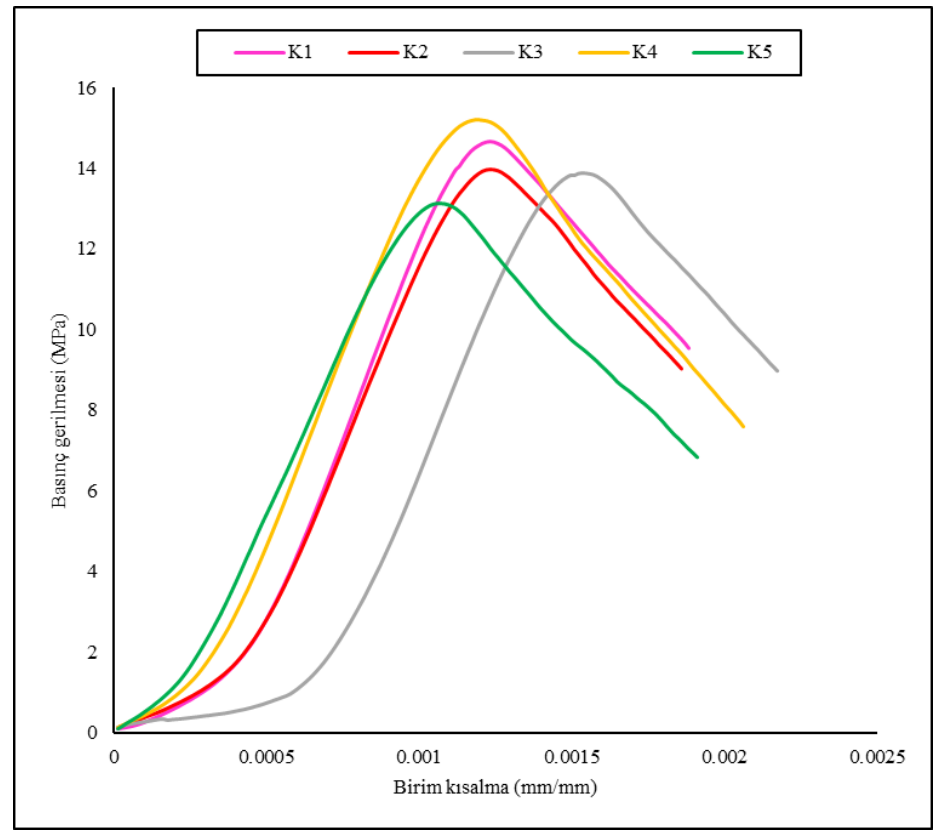

Şekil 2. 7 günlük numunelerde gerilme - birim kısalma ilişkisi.

7 günlük kür süresinin tamamlanması ile K1 kontrol numunesinde $14.65 \mathrm{MPa}$ lık basınç dayanımı tespit edilmiştir. Karışımlara ilave edilen düşük katkı oranındaki silika aerojel içeriği \% 0.25 ve \%0.50 katkı oranları için dayanım değerleri üzerinde farklı etkiler yaratmaktadır. K1 numunesine kıyasla K2 numunesinde \% 4.57 değerinde dayanım düşüşü saptanırken K4 numunesinde ise \%3.74 düzeyinde dayanım artışı saptanmıştır. Sonuçlar, 2 günlük kür süresinden farklı olarak \%0.25 düzeyindeki aerojel içeriğinin kısmi oranda dayanım düşüşüne sebep olduğunu ancak \%0.50 oranındaki aerojel içeriğinin ise 2 günlük kür süresinde olduğu gibi kısmi düzeyde dayanım artışına olanak sağladığını işaret etmektedir. Bununla birlikte eşit aerojel katkı oranında artan aktivatör dozajı numunelerin dayanım değerlerinde kısmi düzeyde düşüşlere neden olmaktadır. Tespit edilen düşüşler K2 numunesine kıyasla K3 numunesinde \%0.78 düzeyinde iken K4 numunesine kıyasla K5 numunesinde \%13.75 seviyesindedir. Artan aktivatör dozajı düşük aerojel katkı oranında sınırlı seviyede dayanım düşüşünü işaret ederken daha yüksek aerojel içeriğinde dayanım farkı artmaktadır.

2 günlük kür süresine benzer şekilde eşit aktivatör dozajında karışımlara ilave edilen aerojel içeriği, \%0.25 katk1 oranı için K1 ve K2 numunelerinin deformasyon yetenekleri arasında bir değişim yaratmamaktadır. Ancak \%0.25' den \%0.50'e çıkan aerojel içeriği, K1 numunesine kıyasla K4 numunesinde kırılma anı için \%11.11 düzeyinde daha yüksek deformasyon kapasitesini işaret etmektedir. Bununla birlikte; K3 numunesinde K2 numunesine kıyasla \%0.78 düzeyinde dayanım düşüşü tespit edilmesine rağmen K3 numunesinde eşit aktivatör dozajında artan aktivatör dozajı sebebiyle deformasyon kapasitesi \%16.66 seviyesinde gelişmektedir. \%0.50 aerojel katkı oranında ise artan aktivatör dozajı dayanım değerlerinde olduğu gibi deformasyon kapasitesinde de düşüşe yol açmaktadır. Bu noktada elde edilen sonuçlar, eşit aerojel katkı oranında artan aktivatör dozajının dayanım değerlerinden çok deformasyon davranışı üzerinde etkili olduğunu işaret etmektedir. 7 günlük kür süresi için mekanik özellikler üzerinde saptanan olumlu etkiler, düşük aerojel katkı oranı (\%0.25) - yüksek aktivatör dozajı (\%0.2) ve yüksek aerojel katkı oranı (\%0.50) - düşük aktivatör dozajı (\%0.1) optimizasyonları ile özetlenebilir.

3) 28 günlük numunelerde basınç dayanımı: Harç numunelerinde 28 günlük kür süresinin tamamlanması ile basınç dayanımları 17.26 - 22.34 MPa aralığında tespit edilmiştir. Şekil 3' de numunelerin gerilme - birim şekil değiştirme ilişkileri görülmektedir. 


\begin{tabular}{|c|c|c|}
\hline & $\begin{array}{l}\text { BŞEÜ Fen Bilimleri Dergisi } \\
7(2), 588-608,2020\end{array}$ & $\begin{array}{l}\text { BSEU Journal of Science } \\
\text { DOI: } 10.35193 / \text { bseufbd.719911 }\end{array}$ \\
\hline & & 88-7575 (http://dergipark.gov.tr/bseufbd) \\
\hline
\end{tabular}

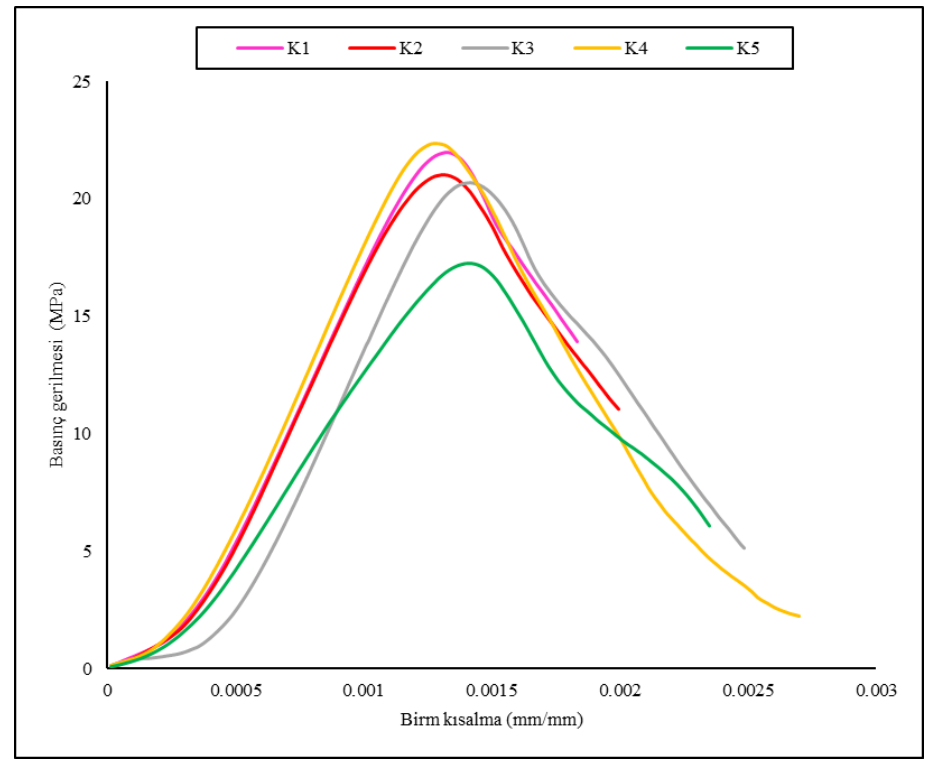

Şekil 3. 28 günlük numunelerde gerilme - birim kısalma ilişkisi.

Kalsiyum - silikat esaslı blok elemanları için yönetmelikler genellikle minimum $5 \mathrm{MPa}$ basınç dayanımını talep edilmektedir [33]. Bu noktada elde edilen basınç dayanımlarının tamamı blok eleman üretimi için standartlardaki minimum dayanım kriterlerini karşılamaktadır. 28 günlük kontrol numunesinde $21.98 \mathrm{MPa}$ lık basınç dayanımı tespit edilmiştir. Karışımlara ilave edilen aerojel ve aktivatör içerikleri incelendiğinde 7 günlük kür süresi sonunda maksimum mekanik performans için önerilen düşük aerojel katkı oranı - yüksek aktivatör dozajı ve yüksek aerojel katkı oranı - düşük aktivatör dozajı optimizasyonlarının 28 günlük kür süresi sonunda da geçerli olduğu görülmektedir. Eşit aktivatör dozajı altında karışımlara ilave edilen $\% 0.25$ ve $\% 0.50$ katkı oranlarındaki silika aerojel içeriği sırasıyla K1 numunesine kıyasla K2 numunesinde \%4.37'lik dayanım düşüşüne neden olurken K4 numunesinde ise \%1.64'lük dayanım artışına olanak sağlamaktadır. Bu noktada eşit aktivatör dozajında artan aerojel katkısı ile elde edilen sonuçlar 7 günlük sonuçlar ile uyumludur. Benzer şekilde, yüksek aerojel katkı oranında artan aktivatör dozajı K4 numunesine kıyasla K5 numunesinde \%22.73'lük ciddi düzeyde düşeşe sebep olurken düşük aerojel katk1 oranında artan aktivatör dozaj1 K2 ve K3 numunelerinde benzer dayanımlara olanak sağlamaktadır. 28 günlük kür süresi saptanan dayanım sonuçları, kontrol numunesine kıyasla daha yüksek dayanımın sadece eşit aktivatör dozajında $\% 0.50$ aerojel katkı oranında elde edilebilmesi, artan aktivatör dozajının yüksek aerojel katkı oranında ciddi dayanım düşüşüne sebep olması açısından 7 günlük sonuçlar ile tam benzerlik göstermektedir.

Numunelerin deformasyon davranışları incelendiğinde ise tüm numunelerde kontrol numunesine kıyasla kırılma anında daha yüksek deformasyon kapasiteleri saptanmıştır. Eşit aktivatör dozajı altında artana aerojel içeriği ile K1 numunesine kıyasla K2 ve K4 numunelerinde saptanan deformasyon kapasitesi gelişimi sırasıyla $\% 5.55$ ve $\% 50$ seviyelerindedir. Tespit edilen sonuçlar $\% 0.25$ aerojel katkı oranında kontrol numunesine kıyasla hiçbir kür süresi için daha düşük deformasyon yeteneğinin oluşmadığını ve ciddi düzeydeki deformasyon kapasite artışının hidratasyonun 7 ve 28 günlük periyotları arasında yaşandığını göstermektedir. Benzer şekilde, \%0.50 aerojel katkı oranında kontrol numunesine kıyasla tüm kür süreleri için daima daha yüksek deformasyon yetenekleri saptanmıştır. Sonuçlar, alkali - aktive edilmiş uçucu kül harçlarında artan aktivatör dozajının olumlu etkisinin dayanım özelliklerine kıyasla deformasyon davranışını üzerinde daha etkili olduğunu vurgulamaktadır. Hidratasyonun 7. günü sonunda daha yüksek mekanik performansı işaret eden düşük aerojel katkı oranı - yüksek aktivatör dozajı ve yüksek aerojel katkı oranı - düşük aktivatör dozajı optimizasyonlarının hidratasyonun 28. günü itibariyle kalıcı hale geldiği gözlemlenmiştir. 


\section{B. Basınç Modülü}

Basınç modülleri, numunelerde lineer - elastik davranışın en net olarak gözlemlendiği maksimum gerilmenin $\% 10-40$ 'ı aralığındaki gerilme- deformasyon bölgesi üzerinden aşağıda görülen eşitlik aracılığı ile hesaplanmıştır.

$$
\mathrm{E}=\Delta \sigma_{40-10} / \Delta \varepsilon_{40-10}
$$

Yukarıda belirtilen eşitlikte "E” basınç modülünü, “ $\Delta \sigma 40-10$ ” ve “ $\Delta \varepsilon 40-10$ ” değerleri ise basınç modülü için hesaplamanın yapıldığı sırasıyla gerilme ve birim kısalma aralıklarını göstermektedir. Şekil 4’ de saptanan basınç modülleri görülmektedir.

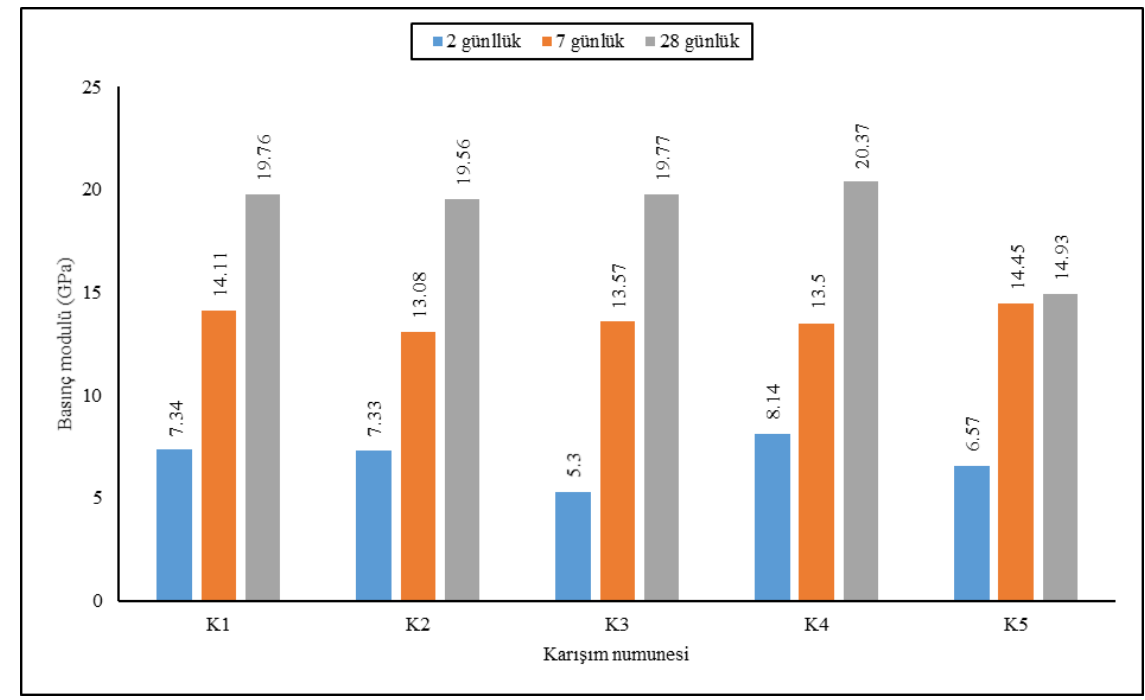

Şekil 4. 2, 7 ve 28 günlük numunelerde saptanan basınç modülleri.

2 günlük kür süresi sonunda kontrol numunesinde $7.34 \mathrm{GPa}$ ' lık basınç modülü tespit edilmiştir. Karışımlara ilave edilen \%0.25 katkı oranındaki aerojel içeriği, dayanım sonuçlarında tartışıldığı gibi 2 günlük kür süresi sonunda birim deformasyon davranış1 üzerindeki nötr etkisi sebebiyle K2 numunesinde de 7.33 GPa'llk eşit kabul edilebilecek modül saptanmıştır. Eşit aktivatör dozajında artan aerojel katkısı ise K1 numunesine kıyasla K4 numunesinde \% 10.89'luk modül artışına olanak sağlamaktadır. Eşit aerojel katkı oranında artan aktivatör dozajının numunelerin deformasyon yeteneklerini arttırması neticesinde K2 numunesine kiyasla K3 ve K4 numunesine kıyasla K5 numunelerinde daha düşük modüller tespit edilmiştir.

7 günlük numunelerde saptanan modül davranışı incelendiğinde, eşit aktivatör dozajında karışımlara ilave edilen aerojel içeriği daha düşük basınç modüllerine yol açmaktadır. Bununla birlikte eşit aerojel katkı oranında artan aktivatör dozajı modül artışına neden olmaktadır. Özellikle \%0.50 aerojel katkı oranında aktivatör dozajına olan hassasiyet artmakta ve maksimum basınç modülü kontrol numunesinin de üzerine çıkarak yüksek aerojel katkı oranı ve yüksek aktivatör dozajında tespit edilmektedir.

Atis ve Karahan [34] deneysel çalışmalarında uçucu kül harçlarında elastisite modülü üzerindeki değişimlerin dayanımdaki değişimlere kıyasla daha sınırlı seviyede olduğunu belirtmişlerdir. Genel olarak elde saptanan elastisite modüllerinin değişimi yukarıdaki tespit ile uyumludur. Hidratasyonun 28. günü itibariyle numunelerde saptanan basınç modülleri özellikle $\% 0.25$ aerojel katkı oranında birbirine yakındır. K2 ve K3 numunelerinde K1 kontrol numunesine kıyasla 19.56 - 19.77 GPa aralığında benzer modüller saptanmıştır. Eşit aktivatör dozajında karışımlara ilave edilen \%0.50 katkı oranındaki aerojel içeriği ise basınç modülünün K4 numunesinde kontrol numunesinin üzerinde saptanmasına olanak sağlamaktadır. Bununla birlikte $\% 0.50$ aerojel katkı oranında artan aktivatör dozajı ciddi düzeyde modül düşüşüne sebep olmakta ve hidratasyonun 7 ve 28 inci 


\begin{tabular}{|c|c|c|}
\hline & $\begin{array}{l}\text { BŞEÜ Fen Bilimleri Dergisi } \\
7(2), 588-608,2020\end{array}$ & $\begin{array}{l}\text { BSEU Journal of Science } \\
\text { DOI: } 10.35193 / \text { bseufbd.719911 }\end{array}$ \\
\hline & & 88-7575 (http://dergipark.gov.tr/bseufbd) \\
\hline
\end{tabular}

günleri arasındaki süreçte K5 numunesi için modül artışı stabil hala gelmektedir. K4 numunesine kıyasla K5 numunesinde kısmi oranda azalan deformasyon yeteneğine karşın ciddi düzeyde azalan dayanım özellikleri de bu duruma yol açmaktadır. Saptanan basınç modülleri, mekanik performans açısından önerilebilecek düşük aerojel katkı oranı - yüksek aktivatör dozajı ve yüksek aerojel katkı oranı - düşük aktivatör dozajı optimizasyonları ile uyumludur.

\section{Basınç Tokluğu}

2, 7 ve 28 günlük kür süreleri sonunda saptanan basınç gerilmesi - birim deformasyon grafikleri aracılığıyla harç numunelerinin tokluk özellikleri basınç tokluğu, pik-öncesi basınç tokluğu ve pik-sonrası basınç tokluğu olmak üzere üç farklı periyottaki tokluk davranışı için ayrı ayrı saptanmıştır. Basınç tokluğu, gerilme birim deformasyon grafiğinin altında kalan tüm alanın dikkate alınması ile hesaplanmıştır. Pik - öncesi ve pik sonrası basınç toklukları ise sırasıyla başlangıç gerilmesi - maksimum gerilme ve maksimum gerilme - kırılma anındaki gerilme bölgelerinin altında kalan alanlar aracılığı saptanmıștır. Numunelerin tokluk kapasiteleri Şekil 5' de sunulmuştur.

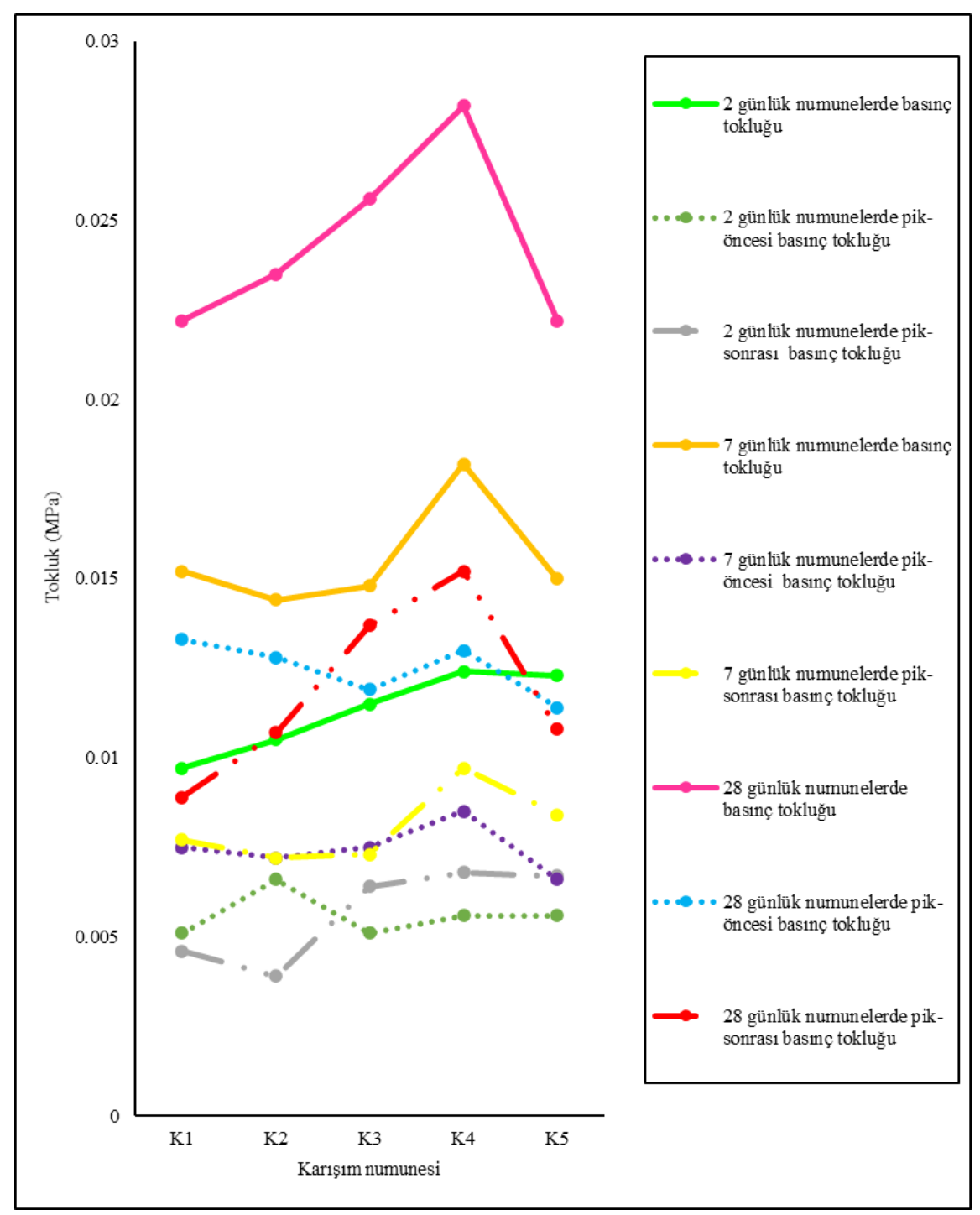

Şekil 5. 2, 7 ve 28 günlük numunelerde saptanan tokluk kapasiteleri. 
2 günlük kür süresi sonunda, kontrol numunesine kıyasla tüm numunelerde daha yüksek tokluk kapasiteleri saptanmıştır. K1 numunesine kıyasla eşit aktivatör dozajında karışımlara ilave edilen aerojel içeriği ile K2 ve K4 numunelerinde sırasıyla $\% 8.24$ ve $\% 27.83$ düzeylerinde tokluk artışları tespit edilmiştir. Özellikle $\% 0.25$ 'ten $\% 0.50$ 'e çıkan yüksek aerojel içeriğinde basınç tokluğu $\% 18.09$ düzeyinde gelişmektedir. Eşit aerojel içeriğinde artan aktivatör dozajı da düşük aerojel katkı oranında daha yüksek düzeyde tokluk gelişimine olanak sağlamaktadır. K2 numunesine kıyasla K3 numunesinde artan aktivatör dozajı sayesinde $\% 9.52$ düzeyinde tokluk gelişimi saptanmıştır. 2 günlük basınç dayanımlarında tartışıldığı üzere; bu noktada artan aktivatör dozajı dayanım gelişmesine olanak sağlamıyorken esas fonksiyonu artan deformasyon kapasitesi aracılığı ile tokluk davranışı üzerinedir. Öte yandan, değisşen aerojel katkı oranı ve aktivatör dozajının basınç tokluğu üzerindeki en önemli etkilerinden biri numunelerin maksimum basınç gerilmesi ile kırılma anı arasındaki süreçte gösterdikleri pik-sonrası tokluk davranışı üzerinedir. K1 kontrol numunesine kıyasla K3, K4 ve K5 numunelerinde sırasıyla \%39.13, \%47.82 ve \%45.65 düzeylerinde pik-sonrası tokluk artışı saptanmıştır.

7 günlük kür süresi sonunda, hidratasyonun 2 ve 7 günlük periyotları arasındaki sürede aerojel katkıı numunelerde tespit edilen kısmi dayanım düşüşleri tokluk davranışı üzerindeki gelişimin de yavaşladığını işaret etmektedir. Bu sebeple, 2 günlük sonuçlardan farklı olarak K2, K3 ve K5 numunelerinde K1 numunesinden sırasıyla $\% 5.26, \% 2.63$ ve \%1.31 düzeylerinde daha düşük tokluk kapasiteleri saptanmıştır. Ancak K4 numunesinde, 2 günlük kür süresinde olduğu gibi, K1 numunesinden daha yüksek düzeyde tokluk davranışı görülmektedir. Yüksek aerojel katkı oranı - düşük aktivatör dozajında elde edilen bu davranış, K1 numunesine kıyasla \%19.73'lük tokluk iyileşmesini işaret etmektedir. Numunelerin pik - sonrası tokluk kapasiteleri incelendiğinde ise özellikle \%0.50 aerojel katkı oranında davranışın oldukça geliştiği görülmektedir. K1 numunesine kiyasla K4 ve K5 numunelerinin pik-sonrasi tokluk kapasiteleri sirasiyla \%25.97 ve \%9.09 düzeylerinde daha yüksektir.

28 günlük numunelerde saptanan basınç tokluğu ve pik-sonrası basınç tokluğu davranışı, alkali-aktive edilmiş uçucu kül harçlarındaki değişen aerojel içeriği ve aktivatör dozajının önemini net olarak ortaya koymaktadır. Kontrol numunesine kıyasla tüm numunelerde daha yüksek tokluk ve pik - sonrası tokluk kapasiteleri saptanmıştır. Ancak, kapasite değiş̧imi düşük dozajdaki aerojel ve aktivatör içeriğine kıyasla oldukça hassas tepki vermektedir. Eşit aktivatör dozajında karışımlara ilave edilen aerojel katkısı K1 numunesine kıyasla K2 ve K4 numunelerinde sırasıyla $\% 5.85$ ve $\% 27.02$ düzeylerinde basınç tokluk artışlarına olanak sağlatmaktadır. K4 numunesinin, \%0.50 aerojel katkı oranı ve düşük aktivatör dozajı ile tüm kür sürelerinde istikrarlı olarak kontrol numunesinden daha yüksek basınç tokluk kapasitesi sergilemesi oldukça dikkat çekicidir. Öte yandan; eşit aerojel katkı oranında artan aktivatör dozajı sadece düşük aerojel katkı oranında tokluk kazancına yol açmaktadır. $\mathrm{Bu}$ sebeple K2 numunesine kıyasla K3 numunesinde \%8.93 düzeyinde daha yüksek tokluk kapasitesi saptanabilmektedir. Optimum aerojel katkı oranında artan aktivatör dozajının $\mathrm{C}-\mathrm{S}-\mathrm{H}$ bağ oluşumunu arttırma yeteneğinin mekanik özellikleri geliştirmesi beklenen bir durumdur [4]. Yüksek aerojel katkı oranında ise artan aktivatör dozajı, K4 numunesinde tespit edilen kazancı ortadan kaldırarak K1 ve K5 numunelerinde yaklaşı olarak benzer tokluk değerlerine neden olmaktadır.

Basınç tokluk kapasitelerinde, \%27 gibi ciddi düzeylerde tokluk kazancı tespit edilmesine rağmen esas mekanik performansın arttığı nokta pik-sonrası basınç tokluğu davranışı ile alakalıdır. K1 numunesine kıyasla K2, K3, K4 ve K5 numunelerinde sirasiyla $\% 20.22, \% 53.92, \% 70.78$ ve $\% 21.34$ düzeylerinde pik-sonrası kapasite artı̧ı kaydedilmiştir. Elde edilen sonuçlar, tokluk kazançlarında tespit edilen artışların 3 katından daha fazlasının pik-sonrası basınç tokluğunda tespit edildiğini işaret etmektedir. Kontrol numunesi ile eşit düzeyde basınç tokluğu kapasitesine sahip olan K5 numunesinin \%21.34 düzeyinde daha yüksek pik-sonrası tokluk performans1 göstermesi dikkat çekicidir.

\section{Clva Porozimetresi Deneyi}

Cıva porozimetresi analizi ile çimento esaslı malzemelerde por yapısı özellikleri geniş bir perspektifte ortaya çıkarılabilmektedir. Analizden elde edilen kümülatif por hacmi - por çapı ilişkileri, spesifik por çapı aralığındaki değişimlerin incelenmesine de olanak tanımaktadır [35]. 28 günlük harç numunelerine uygulanan cıva porozimetresi deneyi sonucunda elde edilen por yapısı parametreleri aşağıda Tablo 5' de görülmektedir. 


\begin{tabular}{|c|c|c|}
\hline & $\begin{array}{l}\text { BŞEÜ Fen Bilimleri Dergisi } \\
7(2), 588-608,2020\end{array}$ & $\begin{array}{l}\text { BSEU Journal of Science } \\
\text { DOI: } 10.35193 / \text { bseufbd.719911 }\end{array}$ \\
\hline & & 88-7575 (http://dergipark.gov.tr/bseufbd) \\
\hline
\end{tabular}

Tablo 5. Civa porozimetresi deney sonuçları.

\begin{tabular}{|c|c|c|}
\hline Karışım numunesi & Porozite (\%) & Alansal-ortalama por çapı (nm) \\
\hline K1 & 18.87 & 7.1 \\
\hline K2 & 17.58 & 8.7 \\
\hline K3 & 20.51 & 6 \\
\hline K4 & 19.79 & 8.4 \\
\hline K5 & 19.7 & 8.2 \\
\hline
\end{tabular}

Nano-boyuttaki malzemelerin çimento matrisine dahil edilmesi, numunelerin por yapılarında cıva porozimetresi analizi ile tespit edilebilecek düzeyde belirgin değişiklikler yaratabilmektedir [36]. Kontrol numunesi K1' de \%18.87'lik toplam porozite değeri tespit edilmiştir. Karışımlara eşit aktivatör dozajında ilave edilen aerojel katkısı K2 numunesinde toplam porozite değerini düşürücü etki yaratırken K4 numunesinde ise artan aerojel içeriği ile porozite artışı saptanmıştır. Öte yandan eşit aerojel katkı oranında artan aktivatör dozajı ise $\% 0.25$ aerojel katkı oranında porozite artışına neden olurken $\% 0.50$ aerojel katkı oranında porozite düşürücü rol oynamaktadır. Bu noktada saptanan sonuçlar $\% 0.25$ ve $\% 0.50$ aerojel katkı oranlarında değişen aerojel ve aktivatör dozajlarının numunelerde farklı eğilimde değişebilen toplam porozite değerlerinin tespit edilebileceğini ortaya koymaktadır.

Numunelerin por yapısı özellikleri ortalama por çapları açısından incelendiğinde ise daha keskin saptamalar ortaya çıkmaktadır. Karışımlara eşit aktivatör dozajında ilave edilen aerojel katkısı gerek K2 gerekse K4 numunelerinde ortalama por çaplarını genişletici bir etki yaratmaktadır. Silika aerojel partikülleri çimento matrisine dahil edildiği zaman partiküllerin matriste konumlandıkları bölgelerin etrafinda zayıf adhezyondan dolayı boşlukların oluşması beklenen bir durumdur [30]. Bu sebeple K1 numunesine kıyasla K2 ve K4 numunelerinin alansal-ortalama por çaplarında sırasıyla $\% 22.53$ ve $\% 18.3$ düzeylerinde artışlar saptanmıştır. Bu durum, silika aerojel katkısı ile por çaplarının artan por hacmi sebebiyle genişleyebileceğini ortaya koyması açısından oldukça makuldür. Benzer şekilde, eşit aerojel katkı oranında artan aktivatör dozajı ortalama por çaplarını tekrardan daraltan bir etki yaratmaktadır. Bağlayıcı malzeme içeriğinde bulunan uçucu külün artan aktivatör dozajı ile hidrolik aktivitesi artmakta ve düşük dozdaki aktivatör içeriğine kıyasla artan aktivatör dozajı ile ilave C-S-H bağı oluşmaktadır. Bu sebeple, eşit aerojel katkı oranında artan aktivatör dozajı ile tespit edilen ortalama por çaplarındaki düşüş de oldukça makuldür. Burada elde edilen sonuçlar, geleneksel toplam porozite anlayışı ile por yapısı özelliklerinin değerlendirilmesinin yetersiz kaldığını ve ortalama por çapları ile daha sağlıklı değerlendirmelerin yapılabileceğini ortaya koymaktadır.

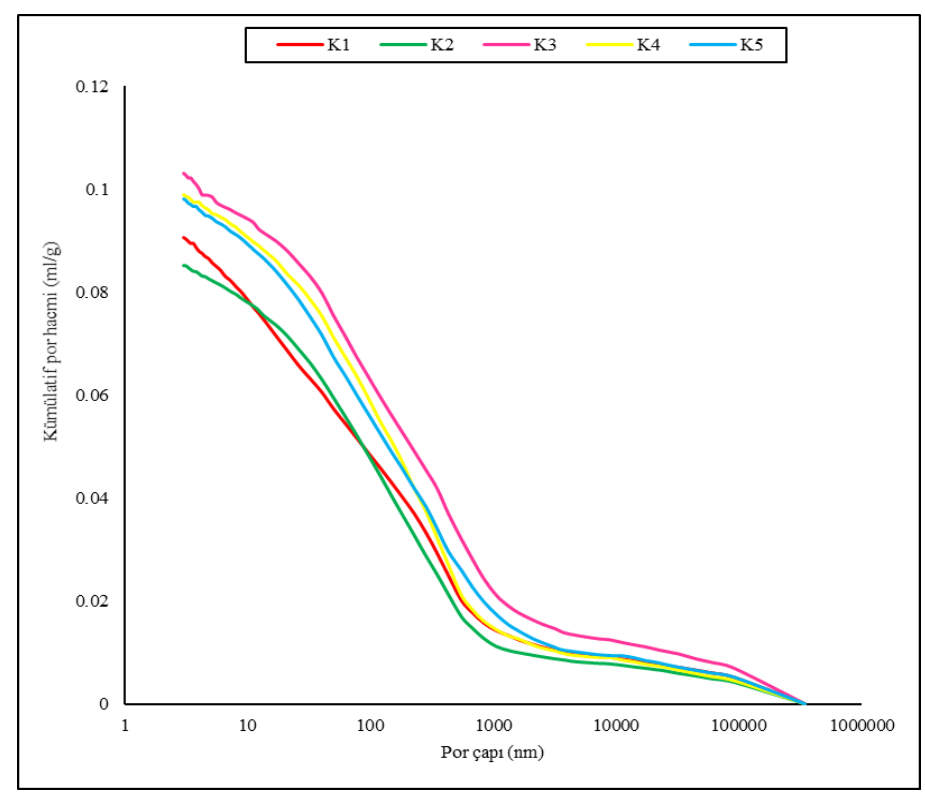

Şekil 6. Harç numunelerinde kümülatif por hacmi - por çapı ilişkisi. 


\begin{tabular}{|c|c|c|}
\hline & $\begin{array}{l}\text { BŞEÜ Fen Bilimleri Dergisi } \\
7(2), 588-608,2020\end{array}$ & $\begin{array}{l}\text { BSEU Journal of Science } \\
\text { DOI: } 10.35193 / \text { bseufbd.719911 }\end{array}$ \\
\hline & & 88-7575 (http://dergipark.gov.tr/bseufbd) \\
\hline
\end{tabular}

Şekil 6' da numunelere ait kümülatif por hacmi - por çapı ilişkisi görülmektedir. Birbirine çok yakın toplam porozite (\%19.79 ve \%19.7) ve alansal-ortalama por çaplarının ( $8.4 \mathrm{ve} 8.2 \mathrm{~nm}$ ) tespit edildiği \%0.50 aerojel katkılı K4 ve K5 numuneleri tüm por çapı aralıkları boyunca birbirine oldukça yakın davranış sergilemektedir. Ancak düşük katkı oranında eşit aerojel içerikli K2 ve K3 numunelerinde gözlemlenen davranış K4 ve K5 numunelerindeki kadar birbirine yakın değildir. Bu durum, numunelerin ölçüm aralığı boyunca birbirine uzak olduğu kabul edilebilecek toplam porozite değerleri (\%17.58 ve \%20.51) ve alansal-ortalama por çapları (8.7 ve $6.0 \mathrm{~nm}$ ) ile uyuşmaktadır. K3 numunesi maksimum düzeyde tespit edilen toplam porozite değeri ile uyumlu olarak tüm por çap aralıkları boyunca grafiğin en üstünde kalacak şekilde en yüksek por hacmini sergilemektedir. K2 numunesi ise toplam porozite değerinin en yakın olduğu K1 kontrol numunesi ile 3-360,000 nm' lik por çapı ölçüm aralığında spesifik por çapı aralıkları için kısmen daha düşük veya daha yüksek olacak şekilde geçişken por hacmi sergilemektedir. Bu noktada, detaylı bir değerlendirme için tüm numunelerde spesifik por çapı aralıklarındaki por hacimlerini esas alan por içeriklerinin dağılımının tespit edilmesi önem arz etmektedir.

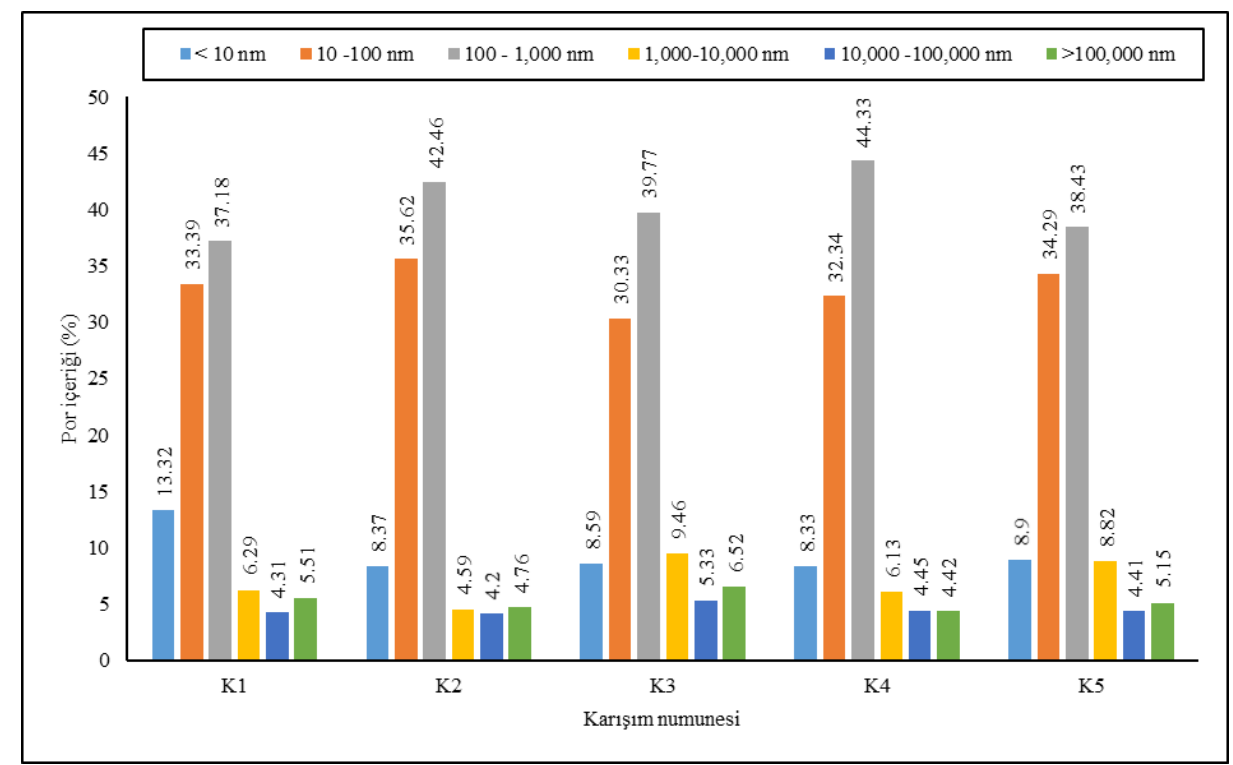

Şekil 7. Harç numunelerinde por içeriklerinin dağılımı.

Şekil 7 'de mikro $(<10 \mathrm{~nm})$, kapiler $(10-10,000 \mathrm{~nm})$ ve makro $(>10,000 \mathrm{~nm})$ boyuttaki por içeriklerinin harç numunelerinin por yapısı içerisindeki dağılımı görülmektedir. Numunelerdeki por içeriklerinin dağılımı incelendiğinde, K1 kontrol numunesinde tespit edilen por içerikleri sırasıyla yaklaşık olarak \%13 - \%77-\%10 düzeninde mikro-kapiler -makro boyutta boşluklar içeren bir por yapısını işaret etmektedir. Bu düzendeki harç por yapısına dahil edilen silika aerojel katkısı, en belirgin değişikliği mikro düzeydeki çaplarda yaratmaktadır. Aerojel içermeyen K1 kontrol numunesinde \%13.32 düzeyinde mikro çap oluşumu tespit edilirken aerojel içeren tüm numunelerde söz konusu çap oluşumu $\% 9$ seviyesinin altındadır. Bu durum karışımlarda partikül düzeyinde ortalama por hacmi 8-10 nm olan silika aerojelin kullanılması nedeniyle oldukça mantıklı gözükmektedir. Bir diğer önemli husus da aerojel içerikli numunelerde kontrol numunesine kıyasla azalan mikro por hacminin hangi yönde değişikliğe uğradığı noktasıdır. Kontrol numunesinde \%76.86 düzeyinde tespit edilen kapiler por oluşumu, aerojel içeren numunelerde \%79.56 - 82.8 aralığında saptanmıştır. Aerojel içeren tüm numunelerde özellikle 100 $-1,000 \mathrm{~nm}$ aralığındaki por oluşumu kontrol numunesinde tespit edilenin üzerinde seyretmektedir. Artan aktivatör dozajı, ilave bağ oluşumu ile bu por çapı aralığındaki por oluşumunu sınırlasa da yine de K3 ve K5 numunelerinde K1 numunesinde ölçülen düzeyin üzerinde por oluşumu saptanmaktadır. Özetle elde edilen por yapısı sonuçları, alkali-aktive edilmiş uçucu kül harçlarında karışımlara düşük katkı oranlarında ilave edilen silika aerojelin numunelerin por yapısında mikro por oluşumunu azaltıcı ve kapiler por oluşumunu arttırıcı yönde değişiklikler yarattı̆̆ını göstermektedir. 


\begin{tabular}{|c|c|c|}
\hline & $\begin{array}{l}\text { BŞEÜ Fen Bilimleri Dergisi } \\
7(2), 588-608,2020\end{array}$ & $\begin{array}{l}\text { BSEU Journal of Science } \\
\text { DOI: } 10.35193 / \text { bseufbd.719911 }\end{array}$ \\
\hline 0 & & 58-7575 (http://dergipark.gov.tr/bseufbd) \\
\hline
\end{tabular}

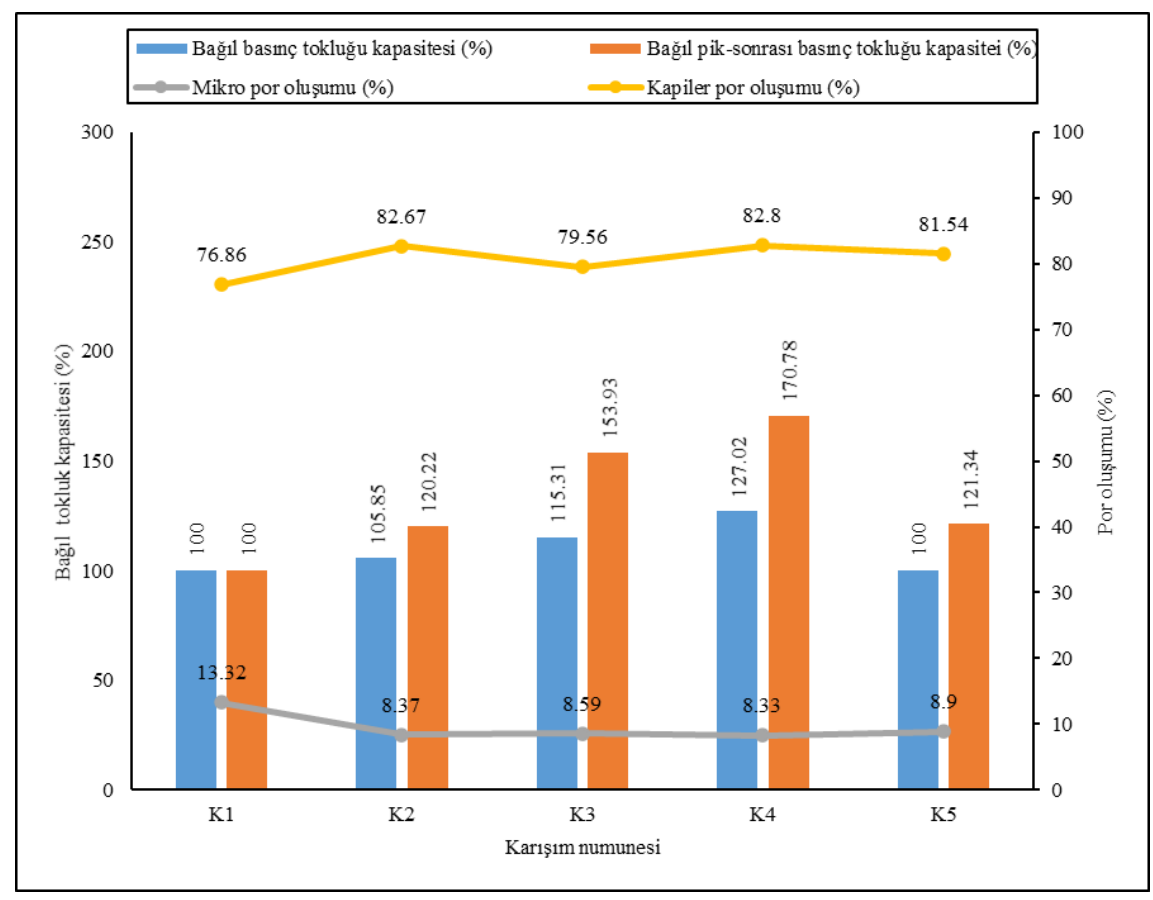

Şekil 8. Harç numunelerinde basınç tokluğu - por içerikleri ilişkisi.

Şekil 8' de 28 günlük harç numunelerinde saptanan basınç tokluğu kapasiteleri ile numunelerdeki por yapısı özellikleri arasındaki ilişki görülmektedir. Grafikte K1 kontrol numunesinde saptanan basınç tokluğu ve pik - sonrası basınç tokluğu kapasiteleri \%100 olarak kabul edilmiş ve değişen aerojel katkı oranı ve aktivatör dozajına bağlı olarak K2, K3, K4 ve K5 numunelerinin tokluk kapasiteleri K1 numunesine kıyasla bağıl olarak ifade edilmiştir. Basınç dayanımı test sonuçlarında tartışıldığı üzere, 28 günlük kür süresi sonunda yaklaşık $20 \mathrm{MPa}$ basınç dayanımına sahip alkali- aktive edilmiş cüruf harçlarında, karışımlara düşük katkı oranları ve dozajlarda ilave edilen silika aerojel ve aktivatör esasen etkisini dayanım değerlerinde değil, kırılma anındaki deformasyon kapasiteleri ve tokluk özellikleri üzerine göstermektedir. Karışımlara çimento ağırlığınca dahil edilen aerojel ve aktivatör içerikleri, düşük aerojel katkılı $(\% 0.25)$ ve yüksek aktivatör dozajlı $(\% 0.2)$ harç numuneleri ile yüksek aerojel katkılı (\%0.50) ve düşük aktivatör dozajlı (\%0.1) numuneler için basınç tokluğu esaslı mekanik özellikleri maksimum verimlilikte geliştirmektedir. Elde edilen basınç tokluğu kazanımları numunelerin por yapısındaki değişen mikro ve kapiler düzeydeki geçişkenlik ile yakından alakalıdır. Çalışmadan elde edilen sonuçlar Lee vd. [37] saptadığı sonuçlar ile uyumludur. Çimento esaslı malzemelerin por yapısında 5 - $10 \mathrm{~nm}$ por çapı aralığındaki düşüş alüminosilikat kökenli $\mathrm{C}-\mathrm{S}-\mathrm{H}$ bağ yapısını arttırmakta ve daha yüksek mekanik özelliklerin tespitine yol açabilmektedir. Öte yandan, basınç tokluğu açısından hiçbir değişikliğin saptanmadığı K5 numunesinde dahi düşük dozajdaki aerojel ve aktivatör içerikleri sayesinde pik - sonrası basınç tokluğu davranışı \%20'nin üzerindeki bir seviyede gelişebilmektedir. Sonuçlar, ortalama $20 \mathrm{MPa}$ basınç dayanımına sahip alkali - aktive edilmiş uçucu kül harçları için numunelerin basınç etkisi altındaki süneklik özelliklerinin silika aerojel katkısı ile ciddi düzeyde geliştirilebileceğini ortaya koymaktadır. Silika aerojel katkısı sayesinde gelişen pik - sonrası basınç tokluğu özellikleri, numunelerin dayanım zorlamasına ulaştığı andan kırılma anına kadar geçen süredeki davranışı iyileştirmektedir. Geçişken mikro - kapiler düzeydeki por yapısı, kalsiyum - silikat yapısında zorlanan liflerin daha az zorlanan liflere gerilme aktarabilme özelliğini geliştirerek tokluk özelliklerini desteklemektedir. 


\begin{tabular}{|c|c|c|}
\hline & $\begin{array}{l}\text { BŞEÜ Fen Bilimleri Dergisi } \\
7(2), 588-608,2020\end{array}$ & $\begin{array}{l}\text { BSEU Journal of Science } \\
\text { DOI: } 10.35193 / \text { bseufbd } 719911\end{array}$ \\
\hline & & 58-7575 (http://dergipark.gov.tr/bseufbd) \\
\hline
\end{tabular}

\section{E. SEM Analizi}

Şekil 9' da 28 günlük numune parçalarının basınç dayanımı testinde kırılma yüzeylerinden elde edilen mikro yapı görüntüleri sunulmuştur.

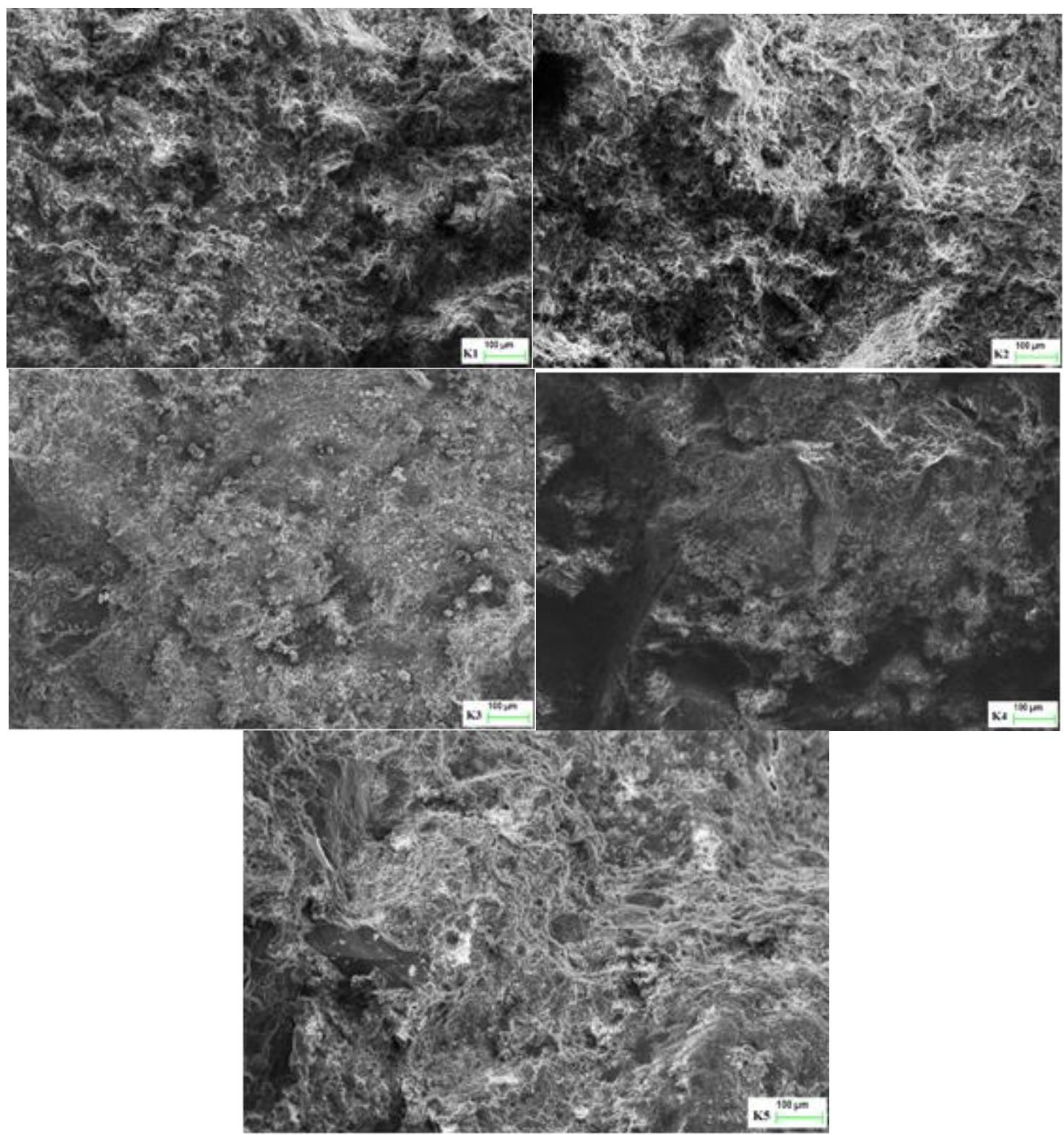

Şekil 9. Harç numunelerinin SEM görüntüleri.

Harç numunelerine ait mikro yapı görüntüleri incelendiğinde, tüm numunelerde bağlayıcı malzeme içeriğinde $\% 50$ düzeyinde kullanılan uçucu kül içeriği nedeniyle küresel formada taneciklerin yer aldığ 1 görülmektedir. Uçucu kül tanecikleri, hızla soğuma neticesinde diğer atık türü bağlayıcı partiküllerinden farklı olarak küresel formda oluşmaktadırlar [21]. Maksimum düzeyde küresel mikro yapı görüntüsü, diğer numunelere kıyasla K1 kontrol numunesinde görüntülenmiş olup artan aktivatör dozajının ve kısmen silika aerojel katkısının etkisiyle uygulanan alkali-aktivasyonun etkinliği morfolojik görüntü üzerine kısmen yansımıştır. Hidratasyon sürecinde, çimento matrisine dahil edilen silika aerojellerin kimyasal reaksiyonlara inert yapıları nedeniyle 
doğrudan dahil olmadıkları ancak matriste zayıf kenetlenmeleri sebebiyle por yapısını derinden etkileyebildikleri bilinmektedir [30]. Öte yandan, kalsiyum - silikat yapısının mikro yapı özellikleri ile por yapısı özellikleri arasında güçlü bir etkileşimin olduğu bilinen bir gerçektir [37]. Harç numunelerinde saptanan alansal-ortalama por çaplarının $6-8.4 \mathrm{~nm}$ aralığında olduğu dikkate alınırsa K1 numunesinde numunenin $7.1 \mathrm{~nm}$ ' lik ortalama por çapına uygun sıkılıkta bir çimento matrisi görülmektedir. K2 numunesinde ise K1 numunesine kıyasla artan ortalama por çapının izleri özellikle çapı 200,000 nm'e varan makro boşluk oluşumu ile görülmektedir. Porozimetre sonuçlarına göre, K3 numunesi tüm numuneler içinde $6 \mathrm{~nm}$ ' lik ortalama por çapı ile en düşük ortalama por çapına sahip olan numunedir. Numunede tespit edilen por çapı bilgisine uygun olarak tüm numuneler arasındaki en sıkı çimento matrisi görüntüsü elde edilebilmiştir. K4 ve K5 numunelerinde ise ortalama por çapları ile uyumlu olarak K5 numunesinde K4'e kıyasla daha yoğun bir matris gözlemlenmektedir.

\section{IV.SONUÇLAR}

Bu çalışmada alkali-aktive edilmiş uçucu kül harç karışımlarına düşük katkı oranlarında ilave edilen silika aerojel katkısının ve aktivatör dozajının numunelerin mekanik, por yapısı ve mikro yapı özellikleri üzerindeki etkisi incelenmiştir. Deneysel çalışmalardan aşağıdaki önemli sonuçlar elde edilmiştir:

- Yaklaşık $20 \mathrm{MPa}$ düzeyinde basınç dayanımına sahip uçucu kül harçlarında karışımlara çimento ağırlığınca düşük katkı oranlarında ilave edilen silika aerojeller, harç por yapısında performans açısından mekanik özelliklere katkı sunabilen nitelikli hava boşlukları olarak katkı sunabilmektedirler.

- Kalsiyum - silikat yapısına ilave edilen silika aerojeller, zorlanan kalsiyum-silikat liflerinin daha az zorlanan liflere gerilme aktarabilme özelliğini geliştirebilmektedir.

- Karışımlardaki silika aerojel içeriği ve artan aktivatör dozajı, numunelerin dayanım değerlerine kıyasla deformasyon davranışlarına etki etmektedir. Bu sebeple 28 günlük kür süresi sonunda \%0.25 aerojel katkılı numunelerde kırılma anındaki deformasyonlar \%50 seviyesinde artabilmektedir.

- Harç karışımlarına ilave edilen düşük katkı oranlarındaki silika aerojel katkısı sayesinde harç numunelerinin basınç etkisi altındaki tokluk kapasiteleri 2, 7 ve 28 günlük kür süreleri için sirasiyla \%29.4, \%13.3 ve \%27 seviyelerinde artabilmektedir.

- Silika aerojel içeriğinin numunelerin mekanik performansı üzerindeki baskın etkisi, basınç tokluğu özelliklerinden çok pik-sonrası basınç tokluğu davranışı ile alakalıdır. Bu sayede harç numunelerinde 2, 7 ve 28 günlük kür süreleri için sırasıyla $\% 47.82, \% 26.97$ ve $\% 70.78$ düzeylerinde pik-sonrası basınç tokluğu gelişimleri saptanmıştır.

- Silika aerojel katkısı harç por yapısındaki mikro çap düzeyini azaltarak kapiler çap oluşumunu arttırmaktadır. Tüm katkılı numunelerde $\% 13$ düzeyinden $\% 9$ seviyesinin altına inen mikro çap oluşumu tokluk gelişimime katkı sunmaktadır.

- Düşük aerojel katkı oranında artan aktivatör dozajı mekanik özellikleri geliştirirken yüksek aerojel katkı oranında düşük aktivatör dozajı optimum mekanik performans için tercih edilmelidir.

Son yıllarda kalsiyum - silikat esaslı yapı elemanlarının üretimine yönelik çabalar tüm endüstrilerde olduğu gibi malzeme alanında da sürdürülebilirlik politikalarını esas almaktadır. Uçucu kül harçları, kalsiyum silikat yapısı ile olan adaptasyonları ve mevcut potansiyelleri göz önünde bulundurularak sıç̧a deneysel çalışmalarda konu edilmektedir. Bu çalışmadan elde edilen sonuçlar, düşük miktardaki silika aerojel katkısının ortalama $20 \mathrm{MPa}$ tasarım basınç dayanımına sahip alkali-aktive edilmiş uçucu kül harçlarının deformasyon yeteneklerini ciddi düzeyde arttırabildiğini işaret etmektedir. Silika aerojeller aracılığı ile elde edilen tokluk kazancı, blok eleman üretimi için silika aerojel katkısını esas alan yenilikçi bir tasarım anlayışını teşvik edici niteliktedir. 


\section{KAYNAKLAR}

[1] Karahan, O. (2017).Transport properties of high volume fly ash or slag concrete exposed to high temperature, Construction and Building Materials, 152, 898-906.

[2] .Hwang,C.-L, Huynh, T.-P. (2015).Investigation into the use of unground rice husk ash to produce ecofriendly construction bricks, Construction and Building Materials, 93, 335-341.

[3] Aliabdo, A.A.,Abd Elmoaty, A. E. M., Aboshama, A.Y. (2016).Utilization of waste glass powder in the production of cement and concrete, Construction and Building Materials, 124, 866-877.

[4] Bostanci, L.,Sola, O.C. (2018).Mechanical properties and thermal conductivity of aerogel incorporated alkali-activated slag mortars, Adances in Civil Engineering, 2018,1 - 9.

[5] Zuo, Y.,Nedeljković, M.,Ye, G. (2019). Pore solution composition of alkali-activated slag/fly ash pastes, Cement and Concrete Research, 115, 230-250.

[6] Provis, J.L.,Bernal, S.A., (2014).Geopolymers and related alkali-activated materials, Annual Review of Materials Research, 44, 299-327.

[7] ASTM C618-01, (2001). Standard Specification for Coal Fly Ash and Raw or Calcined Natural Pozzolan for Use as a Mineral Admixture in Concrete. American Society for Testing and Materials.

[8] Bankowski, P.,Zou, L.,Hodges, R. (2004). Reduction of metal leaching in brown coal fly ash using geopolymers, Journal of Hazardous Materials. 114, 59-67.

[9] Antiohos, S.K.,Tsimas, S. (2007).A novel way to upgrade the coarse part of a high calcium fly ash for reuse into cement systems, Waste Management, 27, 675-683.

[10] Zhuang, X. Y.,Chen, L.,Komarneni, S.,Zhou, C. H.,Tong, D. S.,Yang, H. M.,Yu, W. H.,Wang, H. (2016).Fly ash-based geopolymer: clean production, properties and applications, Journal of Cleaner Production, 125, 253-267.

[11] Kaur, M.,Singh, J.,Kaur, M. (2018). Microstructure and strength development of fly ash-based geopolymermortar: Role of nano-metakaolin, Construction and Building Materials, 190, 672-679.

[12] Akçaozoglu, S.,Atis, C.D. (2011).Effect of Granulated Blast Furnace Slag and fly ash addition on the strength properties of lightweight mortars containing waste PET aggregates, Construction and Building Materials, 25, 4052-4058.

[13] Karahan, O.,Atis, C. D. (2011).The durability properties of polypropylene fiber reinforced fly ash concrete, Materials and Design, 32, 1044-1049.

[14] Yerremala, A.,Chandurdu, R.,Desai, B. (2012).Influence Of Fly Ash Replacement On Strength Properties Of Cement Mortar, International Journal of Engineering Science and Technology, 4, 3657-3665.

[15] Al Zaidi, A.K.A.,Demirel, B.,Atis, C. D. (2019).Effect of different storage methods on thermal and mechanical properties of mortar containing aerogel, fly ash and nano-silica, Construction and Building Materials, 199, 501-507.

[16] Farina, I.,Modano, M.,Zuccaro,G., Goodall, R.,Colangelo, F. (2018).Improving flexural strength and toughness of geopolymer mortars through additively manufactured metallic rebars, Composites Part B, 145, 155-161.

[17] Siad, H.,Lachemi, M.,Sahmaran, M.,Mesbah, H. A.,Hossain, K. M. A. (2018).Use of recycled glass powder to improve the performance properties of high volume fly ash-engineered cementitious composites, Construction and Building Materials, 163, 53-62. 
[18] Guades, E.J. (2016).Experimental investigation of the compressive and tensile strengths of geopolymer mortar: The effect of sand/fly ash (S/FA) ratio, Construction and Building Materials, 127, 484-493.

[19] Xu, F.,Deng, X., Peng, C.,Zhu, J., Chen, J. (2017). Mix design and flexural toughness of PVA fiber reinforced fly ash-geopolymer composites, Construction and Building Materials, 150, 179-189.

[20] Morsy, M. S.,Shoukry, H.,Mokhtar, M. M.,Ali, A. M., El-Khodary, S. A. (2018). Facile production of nanoscale metakaolin: An investigation into its effect on compressive strength, pore structure and microstructural characteristics of mortar, Construction and Building Materials, 172, 243-250.

[21] X. Wu, M. Fan, J. F. Mclaughlin, X. Shen, G. Tan, A novel low-cost method of silica aerogel fabrication using fly ash and trona ore with ambient pressure drying technique, Powder Technology 323 (2018) 310 322.

[22] Ibrahim, M.,Biwole, P. H.,Wurtz, E.,Achard, P. (2014). A study on the thermal performance of exterior walls covered with a recently patented silica-aerogel-based insulating coating, Building and Environment, 81, 112-122.

[23] Hanif, A.,Diao, S.,Lu, Z.,Fan, T.,Li, Z. (2016).Green lightweight cementitious composite incorporating aerogels and fly ash cenospheres - Mechanical and thermal insulating properties, Construction and Building Materials, 116, 422-430.

[24] Liu, Z.-h.,Ding, Y.-d.,Wang, F.,Deng, Z.-p. (2016).Thermal insulation material based on $\mathrm{SiO}_{2}$ aerogel, Construction and Building Materials, 122, 548-555.

[25] Garrido, R.,Silvestre, J. D.,Flores-Colen, I. (2017.Economic and Energy Life Cycle Assessment of aerogelbased thermal renders, Journal of Cleaner Production, 151, 537-545.

[26] Bostanci, L.,Ustundag, O.,Sola, O.C.,Uysal, M. (2019).Effect of various curing methods and addition of silica aerogel on mortar properties, Gradevinar, 71, 651-661.

[27] Cuce, E.,Cuce, P.M.,Wood, C.J.,Riffat, S.B. (2014).Optimizing insulation thickness and analysing environmental impacts of aerogel-based thermal superinsulation in buildings, Construction and Building Materials, 77, 28-39.

[28] Westgate, P.,Paine, K.,Ball, R. J. (2018).Physical and mechanical properties of plasters incorporating aerogel granules and polypropylene monofilament fibres, Construction and Building Materials, 158, 472480.

[29] Haranath, D. (1196). Aerogel the lightest solid known, Resonance, 64-68.

[30] Ng, S., Jelle, B. P., Sandberg, L. I. C., Gao, T., Wallevik, Ó. H. (2015). Experimental investigations of aerogel-incorporated ultra-high performance concrete, Construction and Building Materials, 77, 307-316.

[31] TS EN 196-1, (2016). Çimento deney metotlart- Bölüm 1: Dayanım tayini, Türk Standartları Enstitüsü, Ankara.

[32] TS EN 1015-11, (2000). Kagir harcl- Deney metotlart- Bölüm 11: Sertleşmiş harcın basınç ve eğilme dayanımının tayini, Türk Standartları Enstitüsü, Ankara.

[33] TS EN 771-2, (2015). Kâgir birimler- Özellikler-Bölüm 2: Kireç kumtaşı kâgir birimler.Türk Standartları Enstitüsü, Ankara.

[34] Atis, C. D.,Karahan, O. (2009). Properties of steel fiber reinforced fly ash concrete, Construction and Building Materials, 23, 392-399. 
[35] Zeng, Q.,Mao, T.,Li, H.,Peng, Y. ,82018).Thermally insulating lightweight cement-based composites incorporating glass beads and nano-silica aerogels for sustainably energy-saving buildings, Energy \& Buildings, 174, 97-110.

[36] Oltulu, M.,Sahin, R. (2014).Pore structure analysis of hardened cement mortars containing silica fume and different nano-powders, Construction and Building Materials, 53, 658-664.

[37] Lee, N.K.,Koh, K.T.,An, G.H.,Ryu, G.S. (2017).Influence of binder composition on the gel structure in alkali activated fly ash/slag pastes exposed to elevated temperatures, Ceramics International, 43, 2471-2480. 